\title{
PENGARUH MINAT MEMBACA DAN PENGUASAAN KOSAKATA TERHADAP KETERAMPILAN BERPIDATO
}

\author{
Endang Sulistyaniningsih \\ Program Studi Teknik Informatika, Universitas Indraprasta PGRI \\ Email: esulistyaniningsih@gmail.com
}

\begin{abstract}
Abstrak
Penelitian ini bertujuan untuk mengetahui pengaruh minat membaca dan penguasaan kosakata secara bersama-sama terhadap keterampilan siswa dalam berpidato, pengaruh minat membaca terhadap keterampilan siswa dalam berpidato, dan pengaruh penguasaan kosakata terhadap keterampilan siswa dalam berpidato. Dalam peneltian ini terdapat dua variabel bebas, yaitu minat membaca dan penguasaan kosakata dan satu variabel terikat yaitu keterampilan berpidato. Teknik pengumpulan data menggunakan metode dokumentasi, angket, dan tes. Uji prasyarat analisis yaitu uji normalitas dan uji linieritas. Uji hipotesis penelitian menggunakan analisis korelasi dan analisis regresi. Hasil penelitian menyatakan bahwa terdapat pengaruh yang signifikan minat membaca dan penguasaan kosakata secara bersama-sama terhadap keterampilan berpidato, terdapat pengaruh yang signifikan minat membaca terhadap keterampilan berpidato, dan terdapat pengaruh yang signifikan penguasaan kosakata terhadap keterampilan berpidato.
\end{abstract}

Kata kunci: minat membaca, penguasaan kosakata, keterampilan berpidato

\section{Pendahuluan}

Pembelajaran merupakan kegiatan utama di sekolah sebagai bentuk layanan pendidikan bagi masyarakat. Sekolah diberi kewenangan dan kebebasan untuk memilih strategi, metode, dan teknik pembelajaran yang sesuai dengan karakteristik mata pelajaran, siswa, guru, dan kondisi nyata sumber daya yang tersedia. Salah satu usaha untuk mengoptimalkan pembelajaran adalah dengan memperbaiki pengajaran yang banyak dipengaruhi oleh guru. Karena pengajaran adalah suatu sistem, maka perbaikannya pun harus mencakup keseluruhan komponen dalam sistem pengajaran tersebut. Komponen-komponen yang terpenting adalah tujuan, materi dan evaluasi. Untuk meningkatkan mutu kegiatan belajarmengajar yang dilakukan oleh guru, maka guru harus memiliki dan menguasai perencanaan kegiatan belajar-mengajar, melaksanakan kegiatan yang direncanakan, dan melakukan penilaian terhadap hasil dari proses belajar-mengajar. Kemampuan guru dalam merencanakan dan melaksanakan proses pembelajaran merupakan faktor utama dalam mencapai tujuan pengajaran.

Kemampuan proses pendidikan dan pengajaran di sekolah banyak ditentukan oleh kemampuan berbahasa Indonesia sebagai bahasa komonikasi dan bahasa pengantar pendidikan. Oleh karena itu, bahasa Indonesia merupakan salah satu mata pelajaran penting (termasuk mata pelajaran yang wajib diajarkan pada setiap tingkat satuan pendidikan) dan mempunyai pengaruh besar terhadap kemampuan siswa dalam berkomunikasi. Melalui pembelajaran bahasa Indonesia, siswa dibekali pengetahuan formal bahasa, baik yang terkait dengan kaidah bahasa, proses berbahasa maupun keterampilan berbahasa, yaitu menyimak, berbicara, membaca, dan menulis.

Dari berbagai macam keterampilan bahasa tersebut di atas, salah satunya adalah keterampilan berbicara (pidato). Keterampilan berpidato sangatlah penting dikuasai siswa guna meningkatkan keterampilan berbahasa. Oleh karena itu, keterampilan berpidato perlu diberikan pada siswa sebagai salah satu usaha untuk menumbuhkan minat baca dan meningkatkan penguasaan kosakata dalam keterampilan berpidato pada siswa. Namun 
demikian, pada kenyataannya banyak siswa yang tidak memiliki keterampilan berpidato dengan baik.

Minat secara umum dapat diartikan sebagai suatu kecenderungan yang menyebabkan seseorang berusaha untuk mencari ataupun mencoba aktivitas-aktivitas dalam bidang tertentu. Sebuah pembicaraan pada dasarnya merupakan perwujudan hasil penalaran siswa. Penalaran siswa ini merupakan proses pemikiran untuk memperoleh ide yang logis berdasarkan avidensi yang relevan.

Pada keterampilan berbicara, khususnya pidato, siswa SMP masih banyak yang belum dapat memaparkan atau mengucapkan dengan kata- kata tentang suatu peristiwa, benda, tempat, suasana, atau keadaan yang pernah mereka alami, mereka rasakan, mereka dengar atau mereka lihat. Rendahnya kemampuan siswa SMP dalam berbicara formal dapat ditimbulkan oleh faktor intern dan faktor ekstern. Faktor intern siswa ialah faktor-faktor yang terdapat atau bersumber dari dalam diri siswa itu sendiri. Berdasarkan tugas-tugas perkembangan siswa SMP ada kencenderungan untuk malas berlatih untuk berbicara dalam suasana atau forum ruang formal.

Dari semua uraian di atas maka penulis tertarik meneliti dalam rangka untuk mengetahui seberapa besar: 1) pengaruh minat membaca dan penguasaan kosakata secara bersama-sama terhadap keterampilan siswa dalam berpidato, 2) pengaruh minat membaca terhadap keterampilan siswa dalam berpidato, serta 3) pengaruh penguasaan kosakata terhadap keterampilan siswa dalam berpidato.

Dalam penelitian ini, peneliti mengambil hipotesis sebagai berikut: 1) terdapat pengaruh yang signifikan minat membaca dan penguasaan kosakata secara bersama-sama terhadap keterampilan siswa dalam berbicara (pidato), 2) terdapat pengaruh yang signifikan minat membaca terhadap keterampilan siswa dalam berbicara (pidato), serta 3) terdapat pengaruh yang signifikan penguasaan kosakata terhadap keterampilan siswa dalam berbicara (pidato).

Hasil penelitian ini diharapkan memiliki manfaat, di antaranya: 1) bagi siswa, pengajaran ini diharapkan dapat meningkatkan kemampuan siswa, dan sebagai motivasi dalam berpidato dengan baik dan benar, 2) bagi peneliti, hasil penelitian ini diharapkan dapat menambah pengetahuan terhadap apa yang diteliti, dan sebagai bahan masukan dalam rangka mengembangkan ilmu kebahasaan, serta 3) bagi pengelola pendidikan, hasil penelitian ini dapat dimanfaatkan untuk mengetahui kondisi faktual pembelajaran keterampilan berpidato siswa. Untuk pengembangannya, tambahan buku bacaan baru sangat diperlukan guna membangkitkan motivasi siswa dalam keterampilan berpidato.

\section{Tinjauan Pustaka}

Pada Kamus Besar Bahasa Indonesia (Depdiknas, 2008), pidato diartikan sebagai: 1) mengungkapkan pikiran di bentuk kata-kata yang ditunjukan kepada banyak orang, dan 2) Wacana yang disiapkan diucapkan kepada khalayak. Dalam situs Wikipedia, kata pidato didefinisikan sebagai sebuah kegiatan berbicara di depan umum atau berorasi untuk menyatakan pendapatnya, atau memberikan gambaran tentang suatu hal. Pidato biasanya dibawakan oleh seorang yang memberikan orasi-orasi, dan pernyataan tentang suatu hal/peristiwa yang penting dan patut diperbincangkan.

Keterampilan berbicara khususnya pidato merupakan salah satu keterampilan berbicara yang bersifat produktif lisan, karena dalam kegiatan orang yang berbicara dituntut untuk menghasilkan paparan secara lisan yang merupakan cerminan dari gagasan, perasaan dan pikirannya. Keterampilan berbicara khususnya pidato merupakan kemampuan mengucapkan 
bunyi-bunyi artikulasi atau kata-kata untuk mengekspresikan, menyatakan serta menyampaikan pikiran, gagasan, dan perasaan.

Dalam penyampaian materi pidato diperlukan strategi penyampaian yang baik, hal ini di maksud agar menarik simpati pendengar. Teknik penyampaian pidato yang baik antara lain:

1. Menggunakan bahasa yang mudah dipahami pendengar.

2. Menggunakan contoh dan ilustrasi yang mempermudah pendengar dalam konsep yang abstrak apabila diperlukan.

3. Memberi penekanan dengan cara mengadakan variasi dalam gaya penyajian.

4. Mengorganisasikan materi sajian dengan urut dari hal mudah ke hal yang sulit dan lengkap.

5. Menghindari penggunaan kata-kata yang meragukan dan berlebih-lebihan.

6. Progam atau materi disajikan dengan urutan yang jelas.

7. Berikan ikhtisar butir- butir yang penting, baik selama sajian maupun pada akhir sajian. Gunakan variasi suara dalam memberikan penekanan pada hal-hal yang penting.

8. Kejelasan lafal, intonasi, nada, dan sikap yang tepat agar pendengar tidak bosan atau terkesan monoton.

9. Membuat dan mengajukan pertanyaan untuk mengetahui pemahaman pendengar, minat pendengar, atau sikap pendengar, jika diperlukan.

10. Menggunakan nada suara, volume suara, kecepatan bicara secara bervariasi.

Berdasarkan pada sifat dari isi pidato, pidato dapat dibedakan menjadi:

1. Pidato Pembukaan adalah pidato singkat oleh pembawa acara.

2. Pidato Pengarahan adalah pidato untuk mengarahkan pada suatu pertemuan.

3. Pidato Sambutan, yaitu merupakan pidato yang disampaikan pada suatu acara kegiatan atau peristiwa tertentu yang dapat dilakukan oleh beberapa orang dengan waktu yang terbatas secara bergantian.

4. Pidato Peresmian, adalah pidato yang dilakukan oleh orang yang berpengaruh untuk meresmikan sesuatu.

5. Pidato Laporan, yakni pidato yang isinya adalah melaporkan suatu tugas atau kegiatan.

6. Pidato Pertanggung jawaban, adalah pidato yang berisi suatu laporan pertanggungjawaban.

Menggunakan bahasa tubuh yang mendukung komunikasi anda dengan pendengar.

(Abu Ahmadi, 2003) mengemukakan bahwa minat adalah sikap jiwa seseorang termasuk ketiga fungsi jiwanya (kognisi, konasi, emosi) yang tertuju pada sesuatu dan dalam hubungan itu unsur perasaan yang terkuat. Menurut (Slameto, 2010) minat adalah suatu rasa lebih suka dan rasa keterkaitan pada suatu hal atau aktivitas, tanpa ada yang menyuruh. Minat pada dasarnya adalah penerimaan akan suatu hubungan antara diri sendiri dengan sesuatu diluar diri. Semakin kuat hubungan tersebut, semakin kuat minat.

Dari pengertian di atas dapat dijelaskan kembali bahwa minat, 1) dapat memengaruhi perhatian, belajar, berpikir, 2) mengandung unsur-unsur perasaan, 3) cenderung berbuat aktif dalam suatu pekerjaan, 4) penerimaan akan suatu hubungan antara diri sendiri dengan sesuatu diluar diri, 5) menetap dalam diri subyek untuk merasa tertarik pada bidang tertentu dan merasa senang. Minat adalah kecenderungan yang tetap untuk memperhatikan dan mengenang beberapa kegiatan. Kegiatan yang diminati seseorang, diperhatikan terusmenerus yang disertai dengan rasa senang. Jadi berbeda dengan perhatian, karena perhatian sifatnya sementara (tidak dalam waktu yang lama) dan belum tentu diikuti dengan perasaan senang dan dari situ diperoleh kepuasan.

Membaca adalah proses untuk memperoleh pengertian dari kombinasi beberapa huruf dan kata. Herman (1983) mengartikan bahwa membaca adalah proses untuk mengenal kata dan 
memadukan arti kata dalam kalimat dan struktur bacaan. Hasil akhir dari proses membaca adalah seseorang mampu membuat intisari dari bacaan. Membaca adalah suatu proses yang dilakukan serta dipergunakan oleh pembaca untuk memperoleh pesan, yang hendak disampaikan oleh penulis melalui media kata-kata/bahasa tulis.

Secara operasional Hutabarat (1988) mengartikan minat membaca adalah suatu perhatian yang kuat dan mendalam disertai dengan perasaan senang terhadap kegiatan membaca sehingga mengarahkan anak-anak untuk membaca dengan kemauannya sendiri. Aspek minat membaca meliputi kesenangang membaca, kesadaran akan manfaat membaca, frekuensi membaca dan jumlah buku bacaan yang pernah dibaca oleh anak.

Dalam Kamus Besar Bahasa Indonesia (Depdiknas, 2008), membaca adalah:

1. Melihat serta memahami isi dari apa yang tertulis (dengan melisankan atau hanya dalam hati).

2. Mengeja atau melafalkan apa yang tertulis.

3. Mengucapkan.

4. Mengetahui, meramalkan.

5. Memperhitungkan memahami.

Berdasarkan pendapat para pakar tersebut di atas maka dapat disimpulkan bahwa minat membaca adalah kekuatan yang mendorong anak untuk memperhatikan, merasa tertarik dan senang terhadap aktivitas membaca dengan kemauan sendiri. Aspek minat membaca meliputi kesenangan membaca, frekuensi membaca, dan kesadaran akan manfaat membaca. Minat membaca perlu ditanamkan dan ditumbuhkan sejak anak masih kecil sebab minat membaca pada anak tidak akan terbentuk dengan sendirinya, tetapi sangat dipengaruhi oleh stimulasi yang diperoleh dari lingkungan anak. Keluarga merupakan lingkungan paling awal dan dominan dalam menanamkan, menumbuhkan dan membina minat membaca anak.

Kosakata adalah satuan bahasa terkecil yang memiliki sifat bebas, dapat diujarkan dan mengandung suatu pengertian dan merupakan kekayaan kata yang dimiliki seseorang untuk memahami suatu bacaan. Perkembangan kosakata bahasa Indonesia yang sesuai dengan kaidah adalah akan menjadi kosakata baku. Kosakata ini harus digunakan dalam situasi resmi. Semua kegiatan berbahasa dalam situasi resmi haruslah menggunakan pilihan kosakata yang telah baku. Makna kata terdiri dari: 1) makna lesikal, 2) makna gramatikal, 3) makna lugas, 4) makna kias, 5) denotatif, 6) konotatif, 7) makna referensial, 8) makna non referensial, 9) makana umum, 10) makna khusus, 11) makna idiomatis, dan 12) relasi makna.

\section{Metodologi Penelitian}

Metode yang digunakan dalam penelitian ini adalah survey dengan teknik korelasional. Populasinya adalah seluruh siswa kelas IX SMP Negeri 182, 163, dan 238 di kota Jakarta Selatan dan sampelnya diambil dengan gabungan antara cluster, proporsional dan random. Penelitian dilakukan di kelas IX SMP N 182 sebanyak 36 sampel dan di kelas IX SMP N 163 sebanyak 24 sampel. Dalam peneltian ini terdapat dua variabel bebas yaitu minat membaca dan penguasaan kosakata dan satu variabel terikat yaitu keterampilan berpidato. Teknik pengumpulan data menggunakan metode dokumentasi, angket dan tes. Uji prasyarat analisis yaitu uji normalitas, uji linieritas. Uji hipotesis penelitian yaitu menggunakan analisis korelasi, analisis regresi.

\section{Hasil dan Pembahasan}

1. Pengaruh Minat membaca (X1) dan Penguasaan kosa kata (X2) secara bersama-sama terhadap Keterampilan berpidato $(\mathrm{Y})$ 
Hasil penelitian menyimpulkan bahwa minat membaca dan penguasaan kosakata secara bersamasama telah memberikan pengaruh positif terhadap peningkatan keterampilan berpidato siswa di SMP Negeri di Jakarta Selatan. Hal ini mengandung arti bahwa minat membaca dan penguasaan kosa kata telah memberikan pengaruh yang signifikan terhadap peningkatan keterampilan berpidato siswa di SMP Negeri di Jakarta Selatan.

Dari berbagai macam keterampilan bahasa, salah satunya adalah keterampilan berbicara (pidato). Keterampilan berpidato sangatlah penting dikuasai siswa guna meningkatkan keterampilan berbahasa. Dengan berpidato, siswa akan mampu mengekspresikan pikiran dan perasaannya dengan cerdas sesuai dengan konteks maupun situasi konteks. Keterampilan berpidato akan mampu mencetak generasi masa depan yang kreatif sehingga mampu membentuk tuturan ataupun ujaran yang jelas, komunikatif, runtut dan mudah dipahami.

Oleh karena itu, keterampilan berpidato perlu diberikan pada siswa sebagai salah satu usaha untuk menumbuhkan minat baca dan meningkatkan penguasaan kosakata dalam keterampilan berpidato pada siswa. Namun demikian, pada kenyataannya banyak siswa yang tidak memiliki keterampilan berpidato dengan baik. Siswa mengalami kesulitan dalam memilih kosakata yang tepat sehingga hal itu sangat menghambat perkembangan keterampilan dalam berpidato. Dalam keterampilan berpidato, penguasaan kosakata memegang peranan penting karena dengan penguasaan kosakata yang baik keterampilan berpidato akan berjalan dengan baik.

Selain faktor penguasaan kosa kata yang mempengaruhi keterampilan berpidato adalah minat membaca. Minat secara umum dapat diartikan sebagai suatu kecenderungan yang menyebabkan seseorang berusaha untuk mencari ataupun mencoba aktivitas-aktivitas dalam bidang tertentu. Minat sebagai sifat positif anak terhadap aspek-aspek lingkungan. Dengan minat membaca yang tinggi maka siswa akan banyak memperoleh berbagai konsep, pengetahuan dan informasi sehingga siswa akan terampil dalam berpidato. Minat membaca yang tinggi akan mendorong dan menjadikan kegiatan berpidato akan lebih bermakna dan berkualitas. Apabila minat membaca pada siswa dan penguasaan kosakata sangat rendah maka akan menjadi penyebab siswa kurang memiliki kemampuan dalam berpidato.

2. Pengaruh Minat membaca (X1) terhadap Keterampilan berpidato (Y)

Hasil penelitian menyimpulkan bahwa minat membaca telah memberikan pengaruh positif terhadap peningkatan keterampilan berpidato siswa di SMP Negeri di Jakarta Selatan. Hal ini mengandung arti bahwa minat membaca memberikan pengaruh yang signifikan terhadap peningkatan keterampilan berpidato siswa di SMP Negeri di Jakarta Selatan.

Membaca adalah proses untuk memperoleh pengertian dari kombinasi beberapa huruf dan kata. (The Liang Gie, 1994) mengemukakan arti pentingnya minat dalam kaitannya dengan studi: 1) minat melahirkan perhatian, 2) minat memudahkan terciptanya kosentrasi, 3) minat mencegah gangguan perhatian dari luar, 4) minat memperkuat melekatnya bahan pelajaran dalam ingatan, 5) minat memperkecil kebosanan studi dalam diri sendiri.

Berdasarkan pendapat para pakar tersebut di atas maka dapat disimpulkan bahwa minat membaca adalah kekuatan yang mendorong anak untuk memperhatikan, merasa tertarik dan senang terhadap aktivitas membaca dengan kemauan sendiri. Aspek minat membaca meliputi kesenangan membaca, frekuensi membaca, dan kesadaran akan manfaat membaca. Minat membaca perlu ditanamkan dan ditumbuhkan sejak anak masih kecil sebab minat membaca pada anak tidak akan terbentuk dengan sendirinya, tetapi sangat dipengaruhi oleh stimulasi yang diperoleh dari lingkungan anak.

3. Pengaruh Penguasaan kosakata (X2) terhadap Keterampilan berpidato (Y) 
Hasil penelitian menyimpulkan bahwa penguasaan kosakata telah memberikan pengaruh positif terhadap peningkatan keterampilan berpidato siswa di SMP Negeri di Jakarta Selatan. Artinya, penguasaan kosa kata yang tinggi telah memberikan pengaruh positif terhadap peningkatan keterampilan berpidato siswa di SMP Negeri di Jakarta Selatan.

Kemampuan memaknai kosakata secara tepat merupakan persyaratan yang diperlukan untuk membaca agar dapat memahami maksudnya. Kosakata sangat erat hubungannya dengan penalaran. Jadi, pembaca yang baik harus memahami arti kata yang digunakan oleh penulis. Oleh karena itu, kemampuan kosakata seorang pembaca sangat mempengaruhi pemahaman terhadap bacaan.

Pemahaman suatu bacaan tergantung kemampuan menguasai kosakata yang digunakan oleh penulis, jika dalam membaca anak menjumpai kata dan mengatakan tidak memahami kata tersebut, maka ada beberapa penjelasan yang dapat dikemukakan antara lain : 1) siswa mungkin mengenalnya, tetapi tidak memahami maknanya, 2) mungkin mengetahui secara lisan, tetapi tidak mengenal dalam bentuk tertulis, dan 3) siswa mungkin tidak mengenalnya, sekaligus tidak memperdulikan artinya.

Kesulitan tipe pertama dapat dijelaskan bagaimana ia harus mengembangkan kosakata dan mencari tahu maknanya. Sedangkan jika kesulitannya adalah tipe kedua, maka siswa harus banyak belajar membaca dan mengenal lebih jauh. Kesulitan tipe ketiga maka siswa harus banyak belajar mengembangkan, memahami, serta mengenal lebih jauh kosakata dengan banyak membaca dan menggunakannya dalam bentuk lisan.

Dalam komunikasi, kosakata merupakan hal penting. Pemilihan atau pemakaian kosakata yang digunakan mencerminkan kemampuan seseorang, semakin banyak atau bervariasi kosakatanya semakin tinggi tingkat kemampuannya. Untuk mengetahui kosakata yang dimiliki seseorang kita bisa menggunakan berbagai tes kosakata. Tes kosakata adalah tes yang dimaksudkan mengukur kemampuan siswa terhadap kosakata dalam suatu bahasa baik yang bersifat reseptif maupun produktif. Tes kosakata haruslah dapat menilai kemampuan kosakata siswa, maka harus mempertimbangkan pemilihan bahan atau kosakata yang akan diteskan dan pemilihan bentuk dan cara pengetesan.

\section{Simpulan dan Saran}

Penulis uraikan secara singkat hasil penelitian yang diperoleh di lapangan dan dapat ditarik simpulan sebagai berikut:

1. Terdapat pengaruh yang signifikan minat membaca dan penguasaan kosa kata secara bersama-sama terhadap keterampilan berpidato.

2. Terdapat pengaruh yang signifikan minat membaca terhadap keterampilan berpidato.

3. Terdapat pengaruh yang signifikan penguasaan kosa kata terhadap keterampilan berpidato.

Berdasarkan kesimpulan di atas, penulis memberikan saran sebagai berikut:

1. Hendaknya para guru dan orangtua memperhatikan minat membaca yang dimiliki siswanya/putraputrinya dan selalu memberikan arahan serta motivasi agar siswanya/putra-putrinya mempunyai minat membaca yang tinggi.

2. Hendaknya para pengelola sekolah, khususnya pengelola perpustakaan sekolah secara rutin atau berkala mengadakan kegiatan misalnya berbentuk lomba-lomba yang bertujuan untuk meningkatkan minat membaca para siswa.

3. Hendaknya para guru Bahasa Indonesia selalu mengupayakan agar siswa menguasai kosakata Bahasa Indonesia sebanyak-banyaknya, dan juga membekali diri dengan penguasaan kosakata Bahasa Indonesia agar lebih siap dalam memberikan pembelajaran dan pembekalan kepada siswa khususnya pada materi tersebut.

4. Hendaknya para guru Bahasa Indonesia dapat memadukan antara minat membaca dan kemampuan siswa dalam penguasaan kosakata untuk meningkatkan kemampuan siswa secara khusus dalam berpidato, yang pada akhirnya untuk meningkatkan hasil belajar siswa pada mata pelajaran Bahasa Indonesia. 


\section{Daftar Pustaka}

Abu Ahmadi. (2003). Psikologi Sosial. Jakarta: PT Rineka Cipta.

Depdiknas. (2008). Kamus Besar Bahasa Indonesia Pusat Bahasa Edisi 4. Jakarta: Gramedia Pustaka Utama.

Herman, Hudoyo. (1983). Interaksi Belajar Mengajar. Depdikbud.

Hutabarat. (1988). Cara Belajar. Jakarta: Gunung Mulya.

Slameto. (2003). Belajar dan Faktor-faktor yang Mempengaruhinya. Jakarta: Rineka Cipta.

The Liang Gie. (1987). Cara Belajar yang Efisien. Yogyakarta: Liberty. 